Kravchuk Oleksiy, Doctor of Sciences (Law), the judge of High Anti-Corruption Court, 41, Prospekt Peremohy, Kyiv, 01601, Ukraine ORCID: 0000-0002-7844-2381

Researcher ID: I-5092-2017

\title{
ESTABLISHMENT AND LAUNCH OF HIGH ANTI-CORRUPTION COURT: NEW STAGE IN EXPERIENCE OF UKRAINE IN COMBATING TOP CORRUPTION
}

The article describes the peculiarities of experience of Ukraine in establishment and launching of the High Anti-Corruption Court (HACC), as well as some issues of legal regulation which this court was or will be dealing with in the near future. The peculiarities of the judicial bench formation are highlighted. The competition stages are reviewed; statistics on the candidate number at each stage is given. The role of the Public Council of International Experts and its right to veto with regard to the candidates are highlighted. The legal problems of the jurisdiction of the HACC are analysed, in particular in the cases currently pending before the courts at the stage of its establishment.

Keywords: High Anti-Corruption Court, Ukraine, combating corruption, specialized court.

Кравчук Олексій. Створення та запуск Вищого антикорупційного суду: новий етап досвіду Украӥни у боротьбі з топ-корупцією.

У статті описані особливості досвіду Украӥни щодо створення та діяльності Вищого антикорупиійного суду (ВАC), а також деякі питання правового регулювання, якими ией суд буде займатися найближчим часом. Висвітлено особливості формування складу суду. Переглядаються етапи конкурсу; наводиться статистика щодо кількості кандидатів на кожному етапі. Підкреслюється роль Громадської ради міжнародних експертів та ії право вето щьоо кандидатів. Проаналізовано правові проблеми юрисдикиії ВАС, зокрема у справах, які наразі розглядаються в судах на стадії його створення.

Ключові слова: Вищий антикорупційний суд, Украйна, боротьба з корупиією, спеціалізований суд. 
Relevance of research topic. The key tasks within the Objective 16 of the Agenda for Sustainable Development up to 2030, approved by the UN General Assembly (Resolution 70/1, Clause 16.5), are the significant reduction of corruption and bribery in all its forms. Explaining Objective 16, the UN notes that corruption, bribery, theft and tax evasion cost some US $\$ 1.26$ trillion for developing countries per year; this amount of money could be used to lift those who are living on less than $\$ 1.25$ a day above $\$ 1.25$ for at least six years. Among the institutions most affected by corruption are the judiciary and police (1).

Fight against corruption is identified as one of the main principles for enhancing relations between the Parties to the Association Agreement between the European Union and Ukraine (Article 3), along with the rule of law, good governance, fight against various forms of transnational organized crime and terrorism, promoting sustainable development and effective multilateralism (2).

Article 14 of the Agreement defines the way of the Parties' cooperation in the direction of justice, freedom and security, in particular to strengthen the judiciary, enhance its efficiency, guarantee its independence and impartiality and fight against corruption.

In order to increase the efficiency of consideration of criminal cases on top corruption and within the framework of fulfilment of its international obligations, the Ukrainian Parliament adopted the Law of Ukraine No. 2447 «On High AntiCorruption Court» in June 2018 (3). This law also introduced a number of significant amendments to other laws, including the Criminal Procedure Code of Ukraine (hereinafter referred to as the «CPC») (4).

Problem statement. The High Anti-Corruption Court (hereinafter referred to as the «HACC») was established as a high specialized court for hearing the criminal cases of high profile corruption offenses (crimes) in the first instance and under the appeal procedure established by the law. The establishment of high specialized courts is envisaged by the Constitution of Ukraine (Article 125) (5).

Prior to establishment of the High Anti-Corruption Court in Ukraine, three new executive authorities were established within the framework of the anti-corruption reform. These are the National Agency for Prevention of Corruption (Prevention Authority), the National Anti-Corruption Bureau (Pre-Trial Investigation Authority), and the Specialized Anti-Corruption Prosecutor's Office (a unit of the Prosecutor General' Office). This article is intended to consider the particularities of the experience of Ukraine in establishment and launching of the High Anti-Corruption Court and some of the legal regulation issues which this court deals with or will be dealing with in the near future.

Analysis of recent researches and publications. There are 23 jurisdictions in the world that have specialized anti-corruption courts in one or another form (6). The first anti-corruption court was established in the Philippines in 1979, but more intensive establishment of such courts began since the early 2000s. Among European 
countries, Croatia (2008), Slovakia (2009), Bulgaria (2012) (M. Stephenson, 2016) have these courts in one or another form. The Anti-Corruption Court was established in Albania (2018) (8). The relevant official announcements about establishment of an anti-corruption court were reported by the Moldovan Government (9).

The main criteria of establishment of the anti-corruption courts are integrity, efficiency and specialization (M. Stephenson, 2016). It was the criteria serving the basis for establishment of the HACC, to judicial bench formation of which international experts were involved. The features of the Public Counsel of International Experts (hereinafter referred to as the «PCIE») participation in the establishment of the court are analysed by I.Zabokrytskyi (I. Zabokrytskyy, 2019). Law No. 2423 and relevant amendments to the legislation on the judiciary envisaged additional guarantees of independence for the HACC. The literature emphasizes that the important role in the prosecution of high-level corruption belongs to pre-trial investigation authorities and prosecutors. Moreover, there is even an allegation based on research that has been conducted in the post-communist countries of Eastern Europe (not including Ukraine) and shows that the higher level of corruption charges could be observed in the countries with stronger democratic institutions and availability of journalistic investigations (M. Popova, 2018). It is necessary to agree with the authors who point out the high role of civil society institutions in anticorruption policy, and in particular in the decision to establish the HACC (M. Zaloznaya, 2018).

Presenting main material. Law No. 2447 provided separate competitions for the formation of the judicial bench for the first instance of the High Anti-Corruption Court and for its Chamber of Appeal.

The competitions for the judicial bench formation were held from August 2018 to March 2019 with the participation of the Public Council of International Experts. Six prominent lawyers from the United Kingdom, Denmark, Lithuania, Slovenia, Canada and the United States were included into this Council. These lawyers have solid experience in holding top corruption cases (13).

According to Law No. 2447, the members of the PCIE (not less than 3 persons) actually had the right to veto any candidate, provided there were reasonable doubts about his/her integrity and professionalism. Such a candidate dropped out of the competition. This veto could have been overridden if the PCIE and the High Qualification Commission of Judges of Ukraine (permanent body appointing judges, hereinafter referred to as the «HQCJ») at their special joint meeting voted for it by a majority of the combined composition of these bodies. But at least half of the members of the PCIE had to vote on overriding the veto. 343 candidates submitted applications for participating in the competition to fill 39 positions of judges. 270 of them were admitted to the competition. 
The competition was conducted in several successive stages. In the first two stages, the winners were the candidates in a certain number, the multiple number of vacant positions of judges ( 4 times in the first stage and 3 times in the second stage).

The first stage of the competition involved conducting anonymous written testing in various fields of law. 156 candidates (4 times more than the vacancies of judges) successfully passed the test. In the second stage, the candidates performed an anonymous written practical case. During such a task, it was necessary to write within a limited time a court judgement (sentence for a first instance court or the decision of the court of appeal) in a model criminal case. The second stage was successfully passed by 113 candidates (approximately 3 times more than the number of the vacant positions of judges) (14).

In the third stage, the candidates underwent anonymous psychological testing and interviews with a psychologist.

Following this stage, 49 candidates out of 113 were vetoed by the PCIE. And only 7 of them overcame veto at a joint meeting of the PCIE and HQCJ.

71 remaining candidates had interviews with the HQCJ. After the interview, the HQCJ determined the final scores of the competitors. In determining the final scores, the results of the anonymous test, anonymous practical case, psychological test and interview with the psychologist, interview at the HQCJ and materials of the candidate's file were taken into account. 39 candidates who scored the maximum points were identified as the winners of the competition. Among them, 27 are judges of the first instance and 12 are judges of the Chamber of Appeal. They were recommended for appointment as judges of the High Anti-Corruption Court. After the final interview in the High Council of Justice, one candidate to the Chamber of Appeal withdrew his candidacy.

Based on the recommendations of the High Council of Justice, the President of Ukraine appointed 38 HACC judges by Decree dated April 11, $2019(15 ; 16)$.

After appointment of the judges, the HACC began preparatory work, during which the premises of the court and its Chamber of Appeal were allocated and equipped, the court staff was formed and draft internal court documents were prepared. Judges' meeting in May 2019 set the date for the court to commence its administration of justice to September 05, 2019.

According to Law No. 2447, the HACC and its Chamber of Appeal are separate from each other. Other enterprises or organizations cannot be located in their buildings.

In the course of the study of case law and judicial statistics, as well as the rules of the amended law, a number of issues which the court will face from the day of administration of justice has been identified. This is mainly a matter for the jurisdiction of the court, in particular transfer of the cases currently pending before other courts and new cases. 
The substantive jurisdiction of the HACC, in accordance with the amendments introduced by Law No. 2447 to the CPC, will be determined in Art. 33-1 of the CPC.

A number of cases (listed in Article 33-1 of the CPC) are excluded from the jurisdiction of the general courts and fall within the jurisdiction of the HACC. Appeals in such cases will be submitted to the HACC Chamber of Appeal.

Other courts will not be able to hear the criminal proceedings with regard to the crimes falling within the jurisdiction of the HACC. The only case is when an accused or a victim is or has been a judge or employee of the HACC apparatus and when the criminal proceedings fall within the jurisdiction of this court.

Under new Article 33-1 of the CPC, the jurisdiction of the High AntiCorruption Court will extend to first instance criminal cases upon corruption and some other crimes directly defined by the law (listed below), subject to presence of at least one of the following conditions:

1) committing the crime by a number of officials defined by the law (this is a fairly wide range of persons authorized to perform the functions of public or local authorities who, relatively speaking, can be categorized as «high ranking officials», in particular: the former President, Prime Minister, Ministers, their Deputies, Chairmen and Members of many state collegial bodies of the central executive authorities, members of Parliament, assistants to the President, Prime Minister and Chairman of Parliament, members of the municipal councils, judges, some prosecutors and senior military executives, directors of large companies (business entities) with state or municipal share in the share capital of more than $50 \%$ );

2) offer, promise or provision of undue benefit (crime scenes under Article 369 of the CC) or abuse of influence (crime scenes under Article 369-2 of the Criminal Code of Ukraine (hereinafter referred to as the «CC») (17) committed against such circle of the officials (specified in the first condition);

3) such corruption or other certain crimes directly defined by the law (discussed below) are committed for the amount exceeding (or if a crime subject exceeds) 500 subsistence minimums for able-bodied persons, if the crime is committed by an official of any public authority, law enforcement agency or military unit, local authority or company (business entity) with state or communal share in the share capital of more than $50 \%$.

What list of the crimes according to Art. 33-1 of the CPC is falling within the jurisdiction of the HACC? These are the corruption offenses according to the list established by Art. 45 of CC (these are 11 Articles of the Criminal Code and another 8 Articles in case of committing crimes by abusing office). Herewith, the following crimes shall fall within the jurisdiction of the court: unlawful seizure of property of a company, organization, institution (Art. 206-2 of the CC), laundering of proceeds of crime (Art. 209 of the CC), issuance of regulatory acts that reduce budget revenues or increase budget expenditures contrary to the law (Art. 211 of the CC), declaring false information in assets and income declaration by an official (Art. 366-1 of the CC). 
Together with the envisaged exclusive jurisdiction of the HACC in Art. 33-1 of the CPC, the law made a number of point amendments to other rules of the CPC relating to the jurisdiction of this court at the pre-trial stage and other stages of the criminal proceeding.

For example, the competence of the HACC investigating judges is envisaged with regard to consideration of the requests for conducting unspecified investigative actions (amendments to Chapter 21 of the CPC are introduced), measures for ensuring criminal proceedings (amendments to Art. 132 of the CPC), and preventive measures (amendments to Art. 184, 199, 199, 201 of the CPC).

As the structure of the Criminal Procedure Code has not changed, many Articles of the Code have had to be implemented with the regulations on exceptions (regarding the exclusive jurisdiction of the HACC). Some of the regulations were clearly omitted by the legislator, and as a result, certain conflicts may arise upon the start of administration of justice by the HACC.

In particular, unlike the above examples of amendments to the CPC, the legislator did not reviewed Art. 234 of the CPC, part 2 of which envisages that the search shall be conducted on the basis of the order of the investigating judge of the local general court the territorial jurisdiction of which applies to the pre-trial investigation body. As the HACC is not a local general court but a high specialized court, it is clear that pre-trial investigation bodies will have practical issues about obtaining a search warrant in criminal proceedings that may be subject to the jurisdiction of the HACC in the future.

There are also some problems with formulation of the rules on the jurisdiction of the HACC in Art. 33-1 of the CPC. The two most important points that should be emphasized are the following. The first is the lack of the rules on the jurisdiction over the criminal proceedings for committing the crimes provided for in Art. 33-1 of the $\mathrm{CPC}$ in complicity with several defendants.

The second is that there are no rules on the jurisdiction of the court over the accusations against one person united in one criminal proceeding for committing a number of crimes, some of which fall within the jurisdiction of the HACC, and some of which do not.

The CPC of 1960, by its structure, provided for the possibility of dealing with the first instance criminal cases in the courts of different levels; there was an Article 40 , envisaging that if one person or group of persons were charged with committing several crimes, and such crimes fell within the jurisdiction of courts of different levels, then the case was heard by the superior of those courts (18). In the current CPC of 2012, given the ideology of its structure, a similar regulation (even after establishment of the HACC) had not been provided. 
There is also a problem with the legal technique of formulating the regulation of Art. 33-1 of the CPC. Assuming the exclusive jurisdiction of the HACC, the Law names specific crimes (Articles of the Criminal Code) and sets out the terms under which the criminal proceedings with regard to such crimes would fall within the jurisdiction of the Court. However, the legislator decided not to name these terms but made a reference in such regulation - indicated that these terms were specified in clauses 1-3 of Part 5 of Art. 216 of the CPC. Part 5 of Art. 216 of the CPC determines the competence of detectives of the National Anti-Corruption Bureau of Ukraine (hereinafter referred to as the «NABU»). There are some problems in determining the jurisdiction of the court with regard to competence of the relevant pre-trial investigation body. For example, whether other authorities can file the cases with the HACC if these cases comply with clauses 1-3 of Part 5 of Art. 216 of the CPC, however, do not correspond to the preamble of Part 5 of Art. 216? What actions shall be taken if a prosecutor, pursuant to clause 3 of Part 5 of Art. 216, referred to the NABU's jurisdiction some non-corruption cases? After all, according to the case law of the European Court of Human Rights, the jurisdiction of the court must be established by the law. It cannot be determined by the executive authority which is the Prosecutor's Office (19).

Another important issue is transfer of the cases currently pending before the general district and appeal courts. According to the study of court statistics, there are about 3500 of such cases in the backlog of general courts (20). And these are all complex cases. In the HACC, the cases will only be heard by a panel of three judges. Today, there are only 7 such panels of judges. Therefore, each panel will have about 500 of such cases. In addition, the HACC will receive new cases. There is reasonable concern whether the court will be able to efficiently deal with such a large number of cases within a reasonable timeframe?

To date, the President of Ukraine has tabled a bill proposing that only the cases investigated by the NABU and submitted to the court by the Specialized AntiCorruption Prosecutor's Office will be transferred to the HACC or its Chamber of Appeal from the general courts backlog. The rest of the cases shall fall within the jurisdiction of the HACC only if the proceedings are opened after administration of justice in the HACC was launched (after September 05, 2019). This bill hasn't been adopted by the Parliament by September 05, 2019. Meanwhile, the President of Ukraine has identified it as urgent (21).

Conclusion. The High Anti-Corruption Court is a new specialized court in the judicial system of Ukraine that will hear the criminal cases of high profile corruption offenses in the first instance and under the appeal procedure established by the law. The date of start of administration of justice by the Court is September 05, 2019. 
The establishment of the High Anti-Corruption Court is based on three main ideas - professionalism, integrity and efficiency. This is in line with the general trends of the countries that are establishing specialized anti-corruption courts.

The legislation of Ukraine provided for a special procedure for the establishment of the HACC judicial bench. The HACC judges were appointed as a result of a separate competition with the participation of the international experts having the right to veto. They vetoed 49 candidates out of 113 , and only 7 vetoes were overridden. Integrity and professionalism were the key requirements for the judicial bench formation.

The main criminal cases to be considered by the HACC shall be the cases investigated by the NABU and the Specialized Anti-Corruption Prosecutor's Office, the specialized anti-corruption authorities that were established in Ukraine in 2015.

In cassation proceedings (at the «third instance») the cases, considered by the HACC, will be reviewed according to the standard procedure. For consideration of corruption criminal cases, the Third Judicial Chamber of the Court of Cassation was formed within the Supreme Court.

There are a number of problems in the Ukrainian legislation, including inaccuracy in determining the jurisdiction of the HACC, possibility of transfer of the criminal cases from the backlog of general courts, which according to the statistics are over 3,500. Herewith, there is a bill in the Parliament that addresses some of these issues.

\section{REFERENCES}

1. Sustainable Development goals. Goal 16: Promote just, peaceful and inclusive societies. Retrieved from: https://www.un.org/sustainabledevelopment/ peace-justice/

2. Association Agreement between the European Union and its Member States, of the one part, and Ukraine, of the other part. Retrieved from: https://trade.ec. europa.eu/doclib/docs/2016/november/tradoc_155103.pdf

3. Zakon Ukrainy «Pro Vyshchyi antykoruptsiinyi sud» vid 07.06.2018 № 2447-VIII [Law of Ukraine on 07.06.2018 No. 2447 «On High Anti-Corruption Court»]. Retrieved from: https://zakon.rada.gov.ua/laws/show/2447-19 [in Ukrainian].

4. Kryminalnyi protsesualnyi kodeks Ukrainy vid 13.04.2012 [Criminal Procedure Code of Ukraine on 13.04.2012]. Retrieved from: https://zakon.rada.gov.ua/ laws/show/4651-17 [in Ukrainian].

5. Konstytutsiia Ukrainy vid 28.06.1996 [Constitution of Ukraine on 28.06.1996] Retrieved from: https://zakon.rada.gov.ua/laws/show/254к/96-вp [in Ukrainian]. 
6. Anti-corruption court legislation for 23 countries. U4 Anti-corruption Resource Centre. Retrieved from: https://www.u4.no/anti-corruption-court-legislationfor-23-countries

7. Matthew C. Stephenson, Sofie A. Schütte. Specialized anti-corruption courts: A comparative mapping. U4 Issue December 2016 № 7. Retrieved from: https://www.u4.no/publications/specialised-anti-corruption-courts-a-comparativemapping.pdf

8. Albania: Special Anti-Corruption Court, HJC Starts Candidate Selections. Retrieved from: http://www.rai-see.org/albania-special-anti-corruption-court-hjcstarts-candidate-selections/

9. Pravytelstvo Sandu obeshchaet sozdat v Moldove Antykorruptsyonnyi sud. Tuda pryhlasiat sudei yz-za rubezha [Sandu Government promises to create AntiCorruption Court in Moldova]. Retrieved from: https://newsmaker.md/rus/novosti/ pravitelstvo-sandu-obeshchaet-sozdat-v-moldove-antikorruptsionnyy-sud-tuda-priglas44404 [in Russian].

10. Zabokrytskyy I. Transnational Civil Society Influence on Anti-Corruption Courts: Ukraine's Experience. Global Jurist, 2019. DOI: https://doi.org/10.1515/gj2019-0010 Retrieved from: https://www.degruyter.com/view/j/gj.ahead-of-print/gj2019-0010/gj-2019-0010.xml

11. Popova M., Post V., Prosecuting high-level corruption in Eastern Europe. Communist and Post-Communist Studies, Issue 51 (2018). P. 231-244. https://doi.org/ 10.1016/j.postcomstud.2018.06.004

12. Zaloznaya M., Reisinger W.M., Claypool V. H. When civil engagement is part of the problem: Flawed anti-corruptionism in Russia and Ukraine. Communist and Post-Communist Studies 51 (2018). P. 245-255. https://doi.org/10.1016/j.postcomstud. 2018.06.003

13. PCIE Members. High Qualification Commission of Judges of Ukraine. Retrieved from: https://vkksu.gov.ua/en/public-council-of-international-experts/pciemembers/

14. VKKSU vyznachyla peremozhtsiv konkursu do Vyshchoho antykoruptsiinoho sudu: u pershii instantsii $40 \%$ advokativ ta naukovtsiv, v apeliatsiinii - 50\% [HQCJU has defined the vinners of the Championship to the High Anti-Corruption Court: there are $40 \%$ of attorneys and academics in the first instance, there are $50 \%$ in the appeal]. Retrieved from: https://vkksu.gov.ua/ua/news/wkksu-wiznatchila-pieriemozciwkonkursu-do-wishtchogo-antikorupcijnogo-sudu-u-piershij-instancii-40-adwokatiw-tanaukowciw-w-apieliacijnij-50/ [in Ukrainian]. 
15. Ukaz Prezydenta Ukrainy vid 11.04.2019 №128/2019 «Pro pryznachennia suddiv Vyshchoho antykoruptsiinoho sudu» [Decree of the President of Ukraine on 11.04.2019 №128/2019 «On Appointment of Judges of High Anti-Corruption Court»] Retrieved from: https://www.president.gov.ua/documents/1282019-26474 [in Ukrainian].

16. Ukaz Prezydenta Ukrainy vid 11.04.2019 №129/2019 «Pro pryznachennia suddiv Apeliatsiinoi palaty Vyshchoho antykoruptsiinoho sudu» [Decree of the President of Ukraine on 11.04.2019 №129/2019 «On Appointment of Judges of Chamber of Appeal of High Anti-Corruption Court»] Retrieved from: https://www.president.gov.ua/documents/1292019-26478 [in Ukrainian].

17. Kryminalnyi kodeks Ukrainy vid 05.04.2001 [Criminal Code of Ukraine on 05.04.2001]. Retrieved from: https://zakon.rada.gov.ua/laws/show/2341-14 [in Ukrainian].

18. Kryminalno-protsesualnyi kodeks Ukrainy vid 28.12.1960 [Criminal Procedure Code of Ukraine on 28.12.1960]. Retrieved from: https://zakon.rada.gov.ua/ laws/show/1001-05 [in Ukrainian].

19. Case of Coeme and Others v. Belgium (Applications nos. 32492/96, 32547/96, 32548/96, 33209/96 and 33210/96). Retrieved from: http:/hudoc.echr.coe.int/ fre?i=001-59194

20. Mykhailenko D. Obsiah i struktura predmetnoi pidsudnosti Vyshchoho antykoruptsiinoho sudu ta efektyvne vykonannia yoho zavdannia [Volume and structure of the High Anti-Corruption Court Subject Metter Jurisdiction]. Retrieved from: https://supreme.court.gov.ua/userfiles/media/Muhajlenko.pdf [in Ukrainian].

21. Proekt Zakonu pro vnesennia zminy do Zakonu Ukrainy «Pro Vyshchyi antykoruptsiinyi sud» (shchodo pochatku roboty sudu) vid 29.08.2019 № 1025 [Draft Law On Amendment of Law of Ukraine «On High Anti-Corruption Court» (About beginning of work of the Court) on 29.08.2019 № 1025]. Retrieved from: http://w1.c1.rada.gov.ua/pls/zweb2/webproc4_1?pf3511=66258 [in Ukrainian]. 